\title{
Ultrastructural study of the permeability of in-vitro and ex-vivo human models of human arachnoid granulation CSF outflow pathway
} Deborah M Grzybowski*1,2, David W Holman ${ }^{1}$ and Shelley A Glimcher ${ }^{1}$

\author{
Address: ${ }^{1}$ Biomedical Engineering Department, The Ohio State University, Columbus, OH 43210, USA and ${ }^{2}$ Department of Ophthalmology, The \\ Ohio State University, Columbus, OH 43210, USA \\ Email: Deborah M Grzybowski* - grzybowski.3@osu.edu \\ * Corresponding author
}

from 5 Ist Annual Meeting of the Society for Research into Hydrocephalus and Spina Bifida

Heidelberg, Germany. 27-30 June 2007

Published: 20 December 2007

Cerebrospinal Fluid Research 2007, 4(SuppI I):S6 doi:10.1 186/1743-8454-4-SI-S6

This abstract is available from: http://www.cerebrospinalfluidresearch.com/content/4/SI/S6

(c) 2007 Grzybowski et al; licensee BioMed Central Ltd.

\section{Background}

In communicating hydrocephalus and also idiopathic intracranial hypertension, disturbed CSF dynamics may result from an increased resistance to CSF outflow at the arachnoid granulations (AGs). To better understand the mechanism of CSF egress, we modelled the outflow of CSF through human AGs using both cell culture (in-vitro) and whole tissue (ex-vivo) perfusion models. Ultrastructural studies were done using microparticles, ruthenium red, and TEM and to elucidate the mechanism of fluid flow.

\section{Materials and methods}

Human AG tissue was harvested within $24 \mathrm{~h}$ post-mortem and used to isolate AG cells for growth on filter inserts or fit into an Ussing perfusion chamber. Cell phenotype was identified in culture with immunocytochemical staining. Tissue was perfused at physiologic and increased pressure with serum-free media. Cells/tissue were perfused with fluorescent microparticles, or ruthenium red, and then fixed under experimental pressure. Fixed tissue was processed for TEM or cryo-sectioned and stained for visualization.

\section{Results}

In-vitro serum-free permeability results showed flow through the AG cells was uni-directional in the physiologic direction from the basal to apical $(B \rightarrow A)$ cell mem- brane. The average cellular hydraulic conductivity $\left(\mathrm{Lp}_{\text {ave }}\right)$ for AG cells perfused $B \rightarrow A$ was $93.05 \pm 10.69 \mu \mathrm{l} / \mathrm{min} /$ $\mathrm{mmHg} / \mathrm{cm}^{2}(\mathrm{n}=19)$ with average perfusion pressure $\left(\Delta \mathrm{P}_{\text {ave }}\right)$ across the cell layer of $2.92 \pm 0.08 \mathrm{mmHg}$ which was statistically higher $(\mathrm{p}<0.0001)$ than $\mathrm{Lp}_{\text {ave }}$ for cells perfused $\mathrm{A} \rightarrow \mathrm{B}$ (non-physiologic direction), $0 \mu \mathrm{l} / \mathrm{min} /$ $\mathrm{mmHg} / \mathrm{cm}^{2}(\mathrm{n}=5)$ with $\Delta \mathrm{P}_{\text {ave }}$ of $3.23 \mathrm{mmHg}$.

Ex-vivo serum-free perfusion experiments performed at 5 $\mathrm{mmHg}$ pressure $\mathrm{B} \rightarrow \mathrm{A}$ resulted in $\mathrm{Lp}_{\text {ave }}$ of $7.5 \pm 2.2 \mu \mathrm{L} /$ $\min / \mathrm{mmHg} / \mathrm{cm}^{2}(\mathrm{n}=9)$. The $\mathrm{Lp}_{\text {ave }}$ of tissue perfused in the $\mathrm{A} \rightarrow \mathrm{B}$ direction was $0.06 \pm 0.01 \mu \mathrm{L} / \mathrm{min} / \mathrm{mmHg} / \mathrm{cm}^{2}(\mathrm{n}$ $=3)$. The $\mathrm{Lp}_{\text {ave }}$ at $15.9 \mathrm{mmHg}$ in the $\mathrm{B} \rightarrow \mathrm{A}$ direction was $6.42 \pm 1.76 \mu \mathrm{L} / \mathrm{min} / \mathrm{mmHg} / \mathrm{cm}^{2}(\mathrm{n}=9)$, which was not statistically different from the $\mathrm{Lp}_{\mathrm{ave}}$ at the lower pressure.

Sections of arachnoid membrane with no visible granulations were perfused at physiologic pressure resulting in significant flow, suggesting the presence of microvilli in the membrane contributing to total CSF outflow. The CSF outflow area contributed by the microvilli must be considered in estimating total outflow capacity of the membrane.

Cells perfused physiologically showed extra-cellular cisternal spaces between overlapping AG cells suggesting a pathway for para-cellular fluid transport. Several vacuoles within the cytoplasm, which did not stain with ruthenium 
red, were shown and suggest a trans-cellular pathway for fluid flow.

\section{Conclusion}

AG perfusion results in both in-vitro and ex-vivo models showed that flow was uni-directional and physiologic. TEM showed large intra-cellular vacuoles and extra-cellular cisternal spaces which represent two distinct mechanisms by which AG cells move fluid: 1: Trans-cellular transport via intra-cellular vacuoles, 2: Para-cellular transport via extra-cellular cisterns, which were traced by microparticles. Ex-vivo perfusion results are being studied further to understand the complex relationship between flow through the visible AGs and microvilli.
Publish with Biomed Central and every scientist can read your work free of charge

"BioMed Central will be the most significant development for disseminating the results of biomedical research in our lifetime. " Sir Paul Nurse, Cancer Research UK

Your research papers will be:

- available free of charge to the entire biomedical community

- peer reviewed and published immediately upon acceptance

- cited in PubMed and archived on PubMed Central

- yours - you keep the copyright

Submit your manuscript here:

http://www.biomedcentral.com/info/publishing_adv.asp 